\title{
PHONETIC ASPECTS OF STRONGLY-ACCENTED CZECH SPEAKERS OF ENGLISH
}

\author{
RADEK SKARNITZL and JANA RUMLOVÁ
}

\begin{abstract}
This paper contributes to the study of Czech-accented English by examining multiple pronunciation features, both segmental and prosodic, typically associated with or previously studied in Czech English. We analyzed ten female speakers who had been evaluated as having a strong accent in their English, using auditory and acoustic approaches. In the segmental domain, most of the analyzed speakers used Czech equivalents of the English open vowels $/ æ \mathrm{p} /$ and tended to pronounce a velar plosive after a velar nasal. In the domain of connected speech, linking was very rare in our speakers, and their pitch range tended to be very flat. The results underscore the fact that the label "strong Czech accent" may, in different speakers, refer to different constellations of pronunciation features.
\end{abstract}

Key words: foreign accent, pronunciation, second language acquisition, L1 transfer, Czech English

\section{Introduction}

In the last few decades, English has become the dominant language of international communication, with more non-native speakers using English today than native ones (Crystal, 2002: 10). The inevitable outcome of English being used as an international language (EIL) by speakers of different origins and mother tongues (L1) is that one frequently encounters non-native, or foreign accents. In other words, one commonly hears English spoken with pronunciation patterns which deviate, in terms of their segmental or prosodic properties, from those found in the speech of native speakers.

Foreign-accented speech can be described in terms of several dimensions. The traditional approach focuses on the above-mentioned deviations from native-like pronunciation: accentedness refers to the overall strength of these deviations. It soon became clear, however, that not all pronunciation deviations from L1 are "made equal": their consequences for the success and smooth flow of the communication process vary widely. That is why other dimensions of accented speech have been proposed: intelligibility and comprehensibility have been shown to be only partially related to accentedness (Munro \& Derwing, 1995). The authors demonstrated that even strongly accented speech can be fully intelligible; in other words, listeners may be able to understand the message completely. Comprehensibility refers to the subjective ease of processing of foreign-accented speech: 
while we may be able to understand a speaker's message, this may be only at the price of high cognitive effort. While intelligibility (an indicator of objective understanding) and comprehensibility (subjective understanding) are clearly related, they do represent different constructs (see also Derwing \& Munro, 2009); it is interesting to point out that it has already been 70 years since these two constructs were treated jointly as comfortable intelligibility (Abercrombie, 1949: 120). The more accurate description of pronunciation constructs is associated with a re-evaluation of aims in pronunciation teaching: the earlier Nativeness Principle has been replaced by the Intelligibility Principle (Levis, 2005). As a result, researchers have been attempting to identify those features of pronunciation which have the greatest impact on intelligibility; an excellent recent survey of these endeavours can be found in Levis (2018).

This study will examine English as a foreign language (L2) pronounced by native speakers of Czech. However, its objective is not to examine a particular pronunciation feature with respect to intelligibility or comprehensibility. Rather, we aim to analyze the pronunciation of strongly-accented speakers of Czech English (Skarnitzl, Volín \& Drenková, 2005) and identify which non-native features are most clearly associated with their speech. Naturally, the English pronounced by Czech speakers is not a new research objective. Nevertheless, previous studies have typically addressed one particular pronunciation feature or a group of features, as described in the following section. The aim of the present study is to provide a more global analysis of Czech English.

\section{The study of Czech-accented English}

In this section, we will briefly compare the sound patterns of English and Czech, focusing on those which are known to cause problems to Czech speakers of English, and introduce studies which have examined various aspects of Czech English. Segmental properties will be addressed first, followed by prosodic ones.

\subsection{Vowels in Czech English}

The English vocalic system is considerably more complex than the Czech one, as shown in the schematic comparison of the monophthongs of British English and Czech in Figure 1. There are two major differences between the two systems. First, vowel length is distinctive in Czech, and for three of the pairs (the non-high vowels) the quality of the short and long vowel is the same. There is a qualitative difference between the short and long high front vowels, and a similar difference is emerging in the high back vowels (Skarnitzl \& Volín, 2012). In English, length is traditionally marked in the tense vowels but, in fact, length itself is not distinctive. Second, English has more vowels in its inventory than Czech, and the discrepancy is visible especially in the open region.

It is indeed the open region which causes most problems for Czech learners of English: while Czech has only one vowel pair /a/-/a:/ in the entire open region, there are four vowels occupying this space in English, /æ $\Lambda \mathrm{a}: \mathrm{p} /$. Notable among these is the open front vowel /æ/ which, to our knowledge, is the only one examined from the perspective of production or perception by Czech learners. A part of the title of Šimáčkovás (2003) 


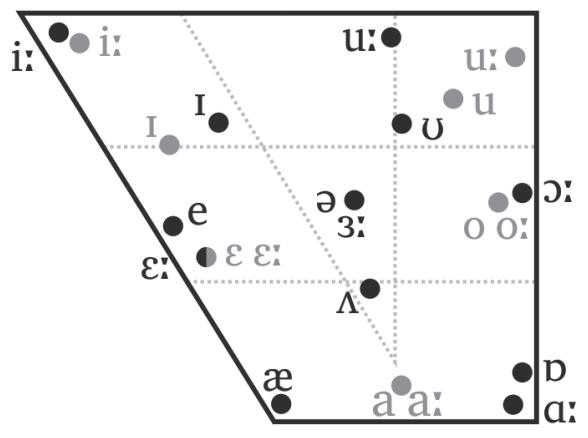

Figure 1. Schematic comparison of the British English (in black) and Czech (in grey) systems of monophthongs. Based on Hawkins and Midgley (2005) for English, and Skarnitzl and Volín (2012) for Czech.

study, "Engela's Eshes", reflects the most frequent realization of Czech speakers of English: the open front /æ/ is typically pronounced as a closer (mid to open-mid) vowel, [ $\varepsilon]$. The contrast with the short /e/ is then achieved by means of duration, with the phrase bad bed typically pronounced [be:d bed] by Czech learners. Šimáčková found that Czech learners rely predominantly on duration when deciding between the English /æ/ and $/ \mathrm{e} /$, and that their production of the two vowels spectrally overlap. Similar results were obtained by Šimáčková and Podlipský (2018): even highly proficient Czech speakers of English used duration to contrast the two vowels, with vowel height being less reliable. Šturm and Skarnitzl (2011) studied perceptual aspects of the vowel /æ/ by two groups of listeners: students who had been instructed in the phonetics and phonology of English and naïve students with no such formal instruction. Their results show that the former group's judgements correlated with the openness of the vowels, as reflected in the value of their F1. In this sense, the instructed group's assessment of Czech speakers' renditions of /æ/ may be regarded as more accurate.

Although the perception or production of other English vowels by L1 Czech listeners have not been studied, we may predict a similar process of equivalence classification (Flege, 1987) with other English vowels in the open region. The short open $/ \mathrm{v} /$ is likely to be qualitatively equated with the Czech mid /o/, and the pair $/ \Lambda /-/ \mathrm{a}: /$ with the Czech open central vowels /a/-/a:/, respectively. However, such pronunciation is likely to impact intelligibility and comprehensibility considerably less than in case of the open front vowel /æ/.

As shown in Figure 1, vowels in the non-high regions are not realized identically in the two languages. Nevertheless, the differences are of a phonetic rather than phonological nature (for instance, the present-day long /u:/ of British English is pronounced as nearly a central vowel, compared to the Czech back $/ \mathrm{u}: /$ ), and the impact on understanding will probably not be dramatic. The mid central vowel /ə/ will be addressed below in sections 2.3 and 2.4, since it constitutes more of a prosodic feature of English than a segmental one.

Finally, it remains to be pointed out that English and Czech also differ in their diphthongs: Czech has three diphthongs closing towards [u], while English has in total seven diphthongs which close towards $[\mathrm{U}]$ and $[\mathrm{I}]$ and also (in non-rhotic varieties) target the centre of the vocalic space, [ə]. However, in spite of these differences, English diphthongs do not seem to constitute a major problem for native speakers of Czech: they may con- 
tribute to a speaker's accentedness, but most likely will not impede intelligibility or comprehensibility.

\subsection{Consonants in Czech English}

The English consonantal system as such is, in comparison with the vocalic one, not too complex. There are certain consonants, though, which are difficult for speakers of other languages. The dental fricatives, $/ \theta /$ and /ð/, are especially notorious. Although their functional load is rather low (i.e., they do not participate in many minimal pairs; see for example Derwing \& Munro, 2015: 74f.) and their incorrect pronunciation did not negatively impact intelligibility (Munro \& Derwing, 2006), there are several reasons why especially the voiced /ð/ should be an important sound for learners of English. It is the sixth most frequent phoneme in connected speech, 11 of the 100 most frequent English words (especially grammatical ones like the, with, they) contain /ð/, and some alternative pronunciations for both the voiced /ð/ and the voiceless $/ \theta /$ are stigmatized throughout the English speaking world (Brown, 2016).

Interestingly, to our knowledge, only various BA- or MA-level theses seem to have dealt with the pronunciation of the dental fricatives by Czech learners of English (e.g. Skarnitzl, 2001). The pronunciation of the voiceless $/ \theta /$ is typically reported as $[\mathrm{f}]$ or $[\mathrm{s}]$, less frequently as $[\mathrm{t}]$, while that of the voiced /ð/ is given as $[\mathrm{d}]$ or $[\mathrm{z}]$, rarely also as $[\widehat{\mathrm{dz}}]$.

Another English consonant whose difficulty is shared by speakers of more languages is the labiovelar approximant /w/. Based on informal observations, Czech speakers are known to realize this sound as a fricative [v] (e.g., which as [vIt]]), but they may also pronounce the English /v/ as an approximant [w] (e.g., very as [werI]).

Some consonants function differently in the system of the two languages. While both Czech and English have the velar nasal [n], it has a distinctive, phonemic function in English (e.g., $\sin / \sin /$ vs. sing /sin/) but only appears in the context of place assimilation in Czech (e.g., banka [banka]). For that reason, Czech speakers of English often pronounce [n] with a following plosive sound (e.g., singing [sIngInk]; see Skarnitzl, 2004).

Moreover, Czech and English have a different way of implementing the voicing contrast. In Czech, the property distinguishing between $/ \mathrm{p} /$ and $/ \mathrm{b} /$ or $/ \mathrm{s} /$ and $/ \mathrm{z} / \mathrm{is}$ phonetic voicing. In contrast, English makes use of the tenseness contrast, which is salient especially in plosives: phonologically voiceless plosives are pronounced as aspirated in stressed positions (e.g., Peter [ $\mathrm{p}^{\mathrm{h}} \mathrm{i}$ tə] $)$. Pospíšilovás (2011) analysis showed that even relatively advanced speakers, with no explicit instruction in the sound patterns of English, aspirate significantly less (i.e., produce shorter voice-onset-time values) than after having received instruction in phonetics and phonology.

Skarnitzl and Šturm (2017) focused on the assimilation of voicing in Czech (and also Slovak) speakers of English across the word boundary. They found that both more and less accented speakers tend to assimilate voiceless consonants to the following voiced one (e.g., nice day as [naIz der]) to a similar extent, but that the more accented group devoiced phonologically voiced consonants more in pre-sonorant contexts (e.g., phase one as [feIs $\mathrm{w} \Lambda \mathrm{n}])$.

Finally, English is rather untypical in that it preserves the voicing contrast also in the final position (e.g., dock/dpk/vs. $\operatorname{dog} / \mathrm{dpg} /$ ); in Czech the voicing contrast is neutralized 
(e.g., spát and spád will both be /spa:t/). In English, the contrast is not achieved through phonetic voicing but uses duration: the vowel will be significantly shorter before voiceless consonants (in dock) than before voiced ones (in $d o g$ ). Not surprisingly, Skarnitzl and Šturm (2016) found that Czech speakers, who had a relatively strong accent in their English, did not exploit duration to cue this contrast.

\subsection{Lexical stress in Czech English}

The two languages whose interactions will be examined in this study differ in the realization of lexical stress. Czech is a language with stress fixed on the first syllable of the prosodic word and serving only a delimitative function, while stress is contrastive in English and stress placement rules are very complicated. The stressed syllable does not bear any marks of positive prominence in Czech (Skarnitzl, 2018); in fact, some studies suggest that the second syllable is frequently pronounced with higher fundamental frequency $\left(f_{0}\right)$ than the stressed one (Palková \& Volín, 2003; Volín, 2008). In English, lexical stress is manifested through longer duration, flatter spectral slope and also higher fundamental frequency (Eriksson \& Heldner, 2015).

Learning the English stress patterns involves not only the placement and adequate acoustic realization of the stressed syllable but also, and perhaps more importantly, mastering the quality of the unstressed syllables. Unstressed syllables tend to be reduced in English; this reduction includes shorter duration, centralization towards the mid central vowel schwa /ə/ (as in together/tə'geðə/), and steeper spectral slope. It is this aspect of English which has received most attention in studies of Czech speakers. Volín, Weingartová \& Skarnitzl (2013) compared the spectral properties of schwa in native British and Czech speakers. While the Czech speakers' formant values did not significantly differ from the native speakers' pronunciation (in other words, vowel quality was comparable to a schwa), the Czech-accented schwas were still too prominent, as reflected in narrower formant bandwidths and flatter spectral slopes. In a follow-up study, more advanced Czech speakers of English were shown to approximate native durational and spectral patterns more than less advanced speakers (Weingartová, Poesová \& Volín, 2014). Similar results were reported by Poesová and Weingartová (2018).

The reduced vowel schwa occurs not only in unstressed syllables of polysyllabic words but also in weak forms of grammatical words such as and, for, that or were. All this contributes to the characteristic rhythm of English, which will be addressed in the following section.

\subsection{Aspects of Czech English related to rhythmic patterning}

The temporal and qualitative reduction of unstressed vowels and unstressed grammatical words is a major factor which determines the nature of rhythmic patterning of English. Volín and Johaníková (2018) examined the normalized duration of selected grammatical words in their weak forms, as pronounced by L1 speakers of British English and Czech, and found that the Czech speakers of English pronounced these words as significantly longer (i.e., less temporally reduced). 
The typical rhythm of English is facilitated by other factors apart from reduction which may be grouped under the heading connected speech processes. The function of these processes in English is "to promote the regularity of English rhythm by compressing syllables between stressed elements and facilitating their articulation" (Alameen \& Levis, 2015: 161). Included among these processes are assimilations of articulation place and manner (e.g., in bed [Im 'bed], in the [In`nə]), coalescence (did you [didża]), consonant-to-vowel and vowel-to-vowel linking (make it [merk $\mathrm{It}]$, see it $\left.\left[\mathrm{si}_{(\mathrm{j})}{ }_{\mathrm{I}} \mathrm{t}\right]\right)$, and elision (did he [didi i]).

In their analysis of weak-form word pronunciation by Czech and British speakers, Volín and Johaníková (2018) focused on these processes as well. They found that the Czech speakers linked grammatical words like $a$, and, in, of much less than the native speakers, rarely elided $[\mathrm{h}]$ in have/has or $[\mathrm{r}]$ in from. In an earlier study, Bissiri and Volín (2010) found that Czech speakers of English with a strong foreign accent glottalized (i.e., did not link) in more than $75 \%$ of all possible instances and that there was little difference within or across phrasal boundaries. Šimáčková, Podlipský and Kolářová (2014) examined linking in advanced speakers of Czech from Moravia (linking is more prevalent in this variety of Czech than in Bohemia) and found that linking occurred between 42 and $64 \%$ of the possible instances, with consonant-to-vowel linking being most frequent. In a related study, Šimáčková, Kolářová and Podlipský (2014) found that the tendency of Czech speakers to link increased at higher speech rates.

All the above-mentioned processes, including the reduction of unstressed syllables and words, contribute to the specific rhythm of the English language; it is therefore clear that rhythm is a true product of its phonological and phonetic patterns.

\subsection{Intonation in Czech English}

Intonational cues may fulfil a number of functions in languages, and languages tend to differ in this respect. This also applies to Czech and English, and the functions are determined, to a large extent, by the rather free word order in Czech and the rather fixed one in English. That is why English relies mainly on melodic cues when expressing prominence, while word order changes may be used alongside or even instead of melodic ones in Czech. In addition, the melody of speech appears to be more important for expressing pragmatic meanings in English (Wichmann, 2005). That may be the reason for the much wider pitch range in English than in Czech, as confirmed by Volín, Poesová and Weingartová (2015). The authors of the study compared Czech and British radio broadcasters and found that pitch range (specifically, the 80-percentile range) was 2 semitones narrower in L1 Czech than in L1 English for both male and female newsreaders. In a following step, native English and Czech non-professional speakers read the same sentences in English. While the pitch range of native British speakers was similar to that of the British newsreaders, it was by over 1 semitone narrower in the L2 speakers of English than in the L1 Czech newsreaders. The results of the study by Volín et al (2015) therefore do not support a straightforward transfer hypothesis, according to which one would predict values intermediate between (or identical to) those of Czech and English. With the pitch range in English as an L2 of Czech speakers even narrower than in L1 Czech, the authors suggest that there must be other factors at play, such as anxiety of the L2 speakers. 


\section{Method}

For this study, we analyzed the speech of ten female speakers. They were native speakers of Czech, and their pronunciation in English was evaluated by three expert phoneticians as strongly accented. The speaker selection method can be justified by our previous study (Skarnitzl et al., 2005) which showed that native English speakers and proficient Czech speakers of English manifest very high correlations when judging the degree of foreign accent. The speakers were asked to read a standard BBC news bulletin; six different texts were used, with an average reading duration of 4 minutes. The recordings were obtained in the sound-treated recording studio of the Institute of Phonetics in Prague, at a sampling rate of $32 \mathrm{kHz}$ and with 16-bit quantization, using the high-quality AKG C4500 $\mathrm{B}-\mathrm{BC}$ condenser microphone. The speakers were given sufficient time for preparation.

As mentioned at the end of the Introduction, the aim of this exploratory study is to identify which of the features of Czech-accented English discussed in the previous section are most reliable. In other words, we are interested in finding out which of the features appear most frequently. The wide selection of the features necessarily affects the choice of the methodology: since vocalic, consonantal, as well as prosodic features will be analyzed here, no single way of analyzing them is possible. That is why both auditory and acoustic analyses are included in this study.

The pronunciation features examined by means of listening are listed in Table 1, along with the number of items for each feature; naturally, the numbers were constrained by the texts, but we aimed at analyzing at least 10 items per feature per speaker. Selection criteria for some of the features are listed in Table 1 as well. The last column provides details about how the individual features were evaluated. Three features were assessed in a binary way (present or absent). Some segmental features were assessed either in a ternary manner (with 2 corresponding to, for instance, a native-like open [æ], 0 to a completely Czech $[\mathrm{e} / \varepsilon]$, and 1 to an intermediate realization), or we noted the specific realization (e.g., for the vowel schwa, we noted the vocalic quality the specific realization was closest to). For lexical stress, we noted the syllable which was stressed in the particular word. The auditory evaluations were entered into a special tier in Praat (Boersma \& Weenink, 2018).

The only features which were analyzed acoustically in this study concern melodic patterning. As Czech English has been found to be very flat (see section 2.5), a measure of pitch range was a natural choice for analysis. For this purpose, we split the utterances into breath groups (portions of the speech signal between two intakes of breath). Values of $f_{0}$ were extracted using autocorrelation in Praat every $10 \mathrm{~ms}$, the contour was smoothed by a $10-\mathrm{Hz}$ filter, interpolated, and converted into the Praat PitchTier objects where the contours were carefully inspected and manually corrected to reduce the most salient measurement errors, especially octave jumps and spurious $f_{0}$ measurements in creaky phonation or voiceless portions of the signal. Finally, the curves were once again interpolated to approximate the perceived pitch contour. From these manually corrected $f_{0}$ objects, we calculated the 80 -percentile range of each speaker (i.e., a range value where the lower and upper $10 \%$ values are ignored).

In addition, we analyzed the difference in mean $f_{0}$ in the stressed vowel and the vowel in the following syllable; as Czech speakers have been shown to pronounce the poststressed syllable higher than the stressed one, the aim was to determine whether they 
Table 1. Features analyzed by listening (see text).

\begin{tabular}{|c|c|c|c|c|}
\hline & Feature & Items & Selection criteria & Scoring \\
\hline \multirow{2}{*}{$>$} & $æ$ & 113 & & $2-1-0$ \\
\hline & $\mathrm{p}$ & 124 & & $2-1-0$ \\
\hline \multirow{8}{*}{$u$} & n & 94 & & specific realization \\
\hline & $\theta$ & 58 & & specific realization \\
\hline & д & 159 & include as many lexical words as possible & specific realization \\
\hline & $\mathrm{v}$ & 162 & & $2-1-0$ \\
\hline & $\mathrm{W}$ & 212 & & $2-1-0$ \\
\hline & prevocalic I & 103 & $\begin{array}{l}\text { include word-initial and -medial items, as } \\
\text { well as those following a plosive }\end{array}$ & specific realization \\
\hline & aspiration in $\mathrm{p}, \mathrm{t}, \mathrm{k}$ & 307 & $\begin{array}{l}\text { include stress on the first and other than } \\
\text { first syllable, and words with preceding /s/ }\end{array}$ & present - absent \\
\hline & voicing assimilation & 64 & & present - absent \\
\hline \multirow{3}{*}{$\begin{array}{l}\vec{z} \\
0 \\
0 \\
0 \\
0\end{array}$} & lexical stress & 342 & $\begin{array}{l}\text { aim for two-, three- and four-syllabic words } \\
\text { with stress on another than the first syllable }\end{array}$ & stressed syllable \\
\hline & ә & 361 & $\begin{array}{l}\text { include word-initial, -medial, and -final, in } \\
\text { lexical words only }\end{array}$ & specific realization \\
\hline & linking & 227 & $\begin{array}{l}\text { include linking to lexical and grammatical } \\
\text { words }\end{array}$ & present - absent \\
\hline
\end{tabular}

transfer this tendency to their L2 English. The $f_{0}$ values were extracted from the manually corrected PitchTiers using a Praat script; only those words were used which were marked for lexical stress (see Table 1).

The auditory data were extracted from the evaluation tier using a Praat script and subsequently processed in the R programme (R Core Team, 2015). The PitchTiers were processed in the rPraat package (Bořil \& Skarnitzl, 2016). All visualizations were performed in the ggplot2 package (Wickham, 2009).

\section{Results and discussion}

The pronunciation of the analyzed speakers will be described in five sections, following the structure of the introduction.

\subsection{Vowels}

The two target open vowels of English - the front /æ/ and the back / $/$ - were expected to be realized as their Czech counterparts, the (open-)mid / $/ \varepsilon /$ and /o/, respectively. Figure 2 shows that this hypothesis is largely confirmed: only three realizations of $/ \mathrm{p} /$ and one of /æ/, produced by three different speakers, were evaluated as target-like. 


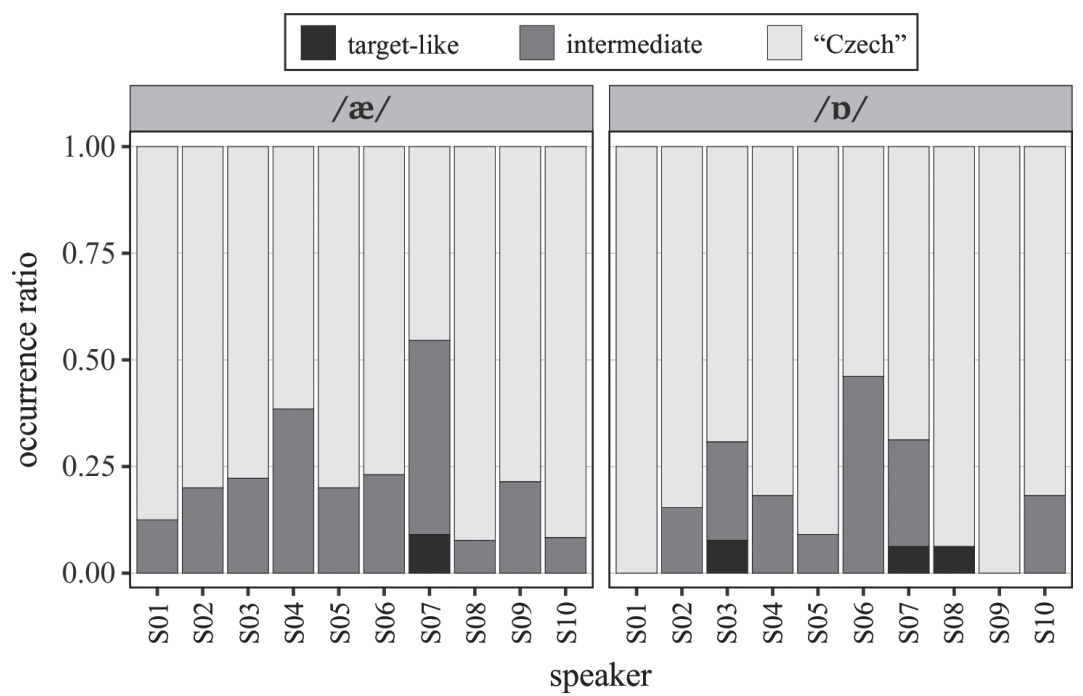

Figure 2. Proportion of target-like, intermediate, and "Czech"-like realizations of the vowels /æ/ and /p/.

\subsection{Consonants}

We will first focus on those consonantal sounds which do not exist in Czech at all, starting with the dental fricatives. As the two dental fricatives, the voiceless $/ \theta /$ and the voiced /ð/, occur in different word types, they will be addressed separately. The realizations of the voiceless $/ \theta$ / by our speakers are illustrated in Figure 3. First of all, it is clear at first sight that there is much greater variability between speakers: while speakers S01, S08 and S10 pronounced all the target sounds as voiceless dental fricatives, speakers S04, S05 and S06 substituted more than $75 \%$ of $/ \theta /$-items by different consonants. The most frequent substitute was the plosive [t], with the exception of speaker S05 who used [s] more; a closer examination reveals that the [s] substitutions occur predominantly at the end of words like death, month(s) or both. It is noteworthy that [f], phonetically the closest candidate for a substitute of English $/ \theta /$, was only pronounced once by speaker S04 in the word three. The affricate [ $[\mathrm{ts}]$ was used in similar words (three, thirty), and the sequence [th] appeared in authority, thousand and strengthening. The voiced [ð] occurred in the context of regressive voicing assimilation, in the phrase foot and mouth disease.

The voiced dental fricative / $/$ / was pronounced as [ $[0]$ in $33 \%$ cases and substituted by the plosive $[\mathrm{d}]$ in $58 \%$ cases. On the one hand, / $/$ is very frequent in grammatical words like the, this or than; on the other hand, it also occurs in lexical words like father, southern or together. As shown in Figure 4, the substitutions of the Czech speakers differ with respect to these categories: [d] occurs with higher frequency in the grammatical words, while [ð] is pronounced in about two thirds of the cases in lexical words. The preposition with is depicted separately in the figure, since it manifests specific substitutions [t], [s] and $[\theta]$ ([t] was also pronounced once in the words gathering and the). 


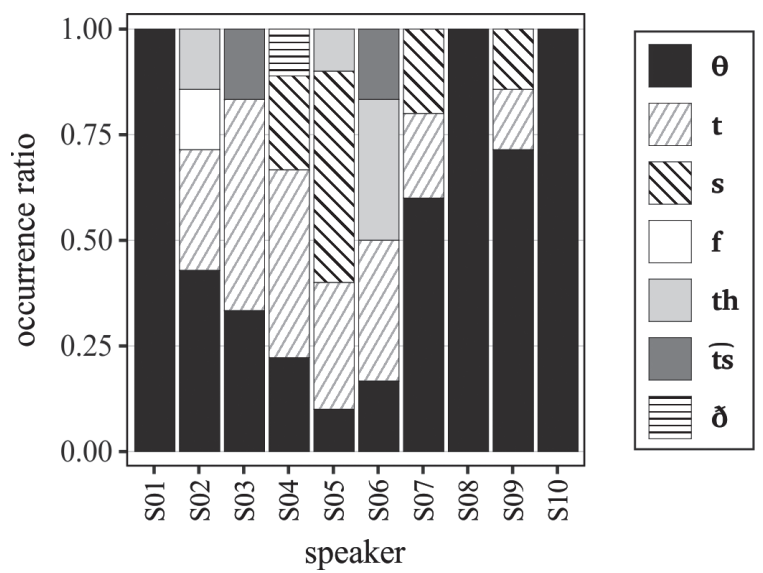

Figure 3. Proportion of realizations of the voiceless dental fricative $/ \theta /$.

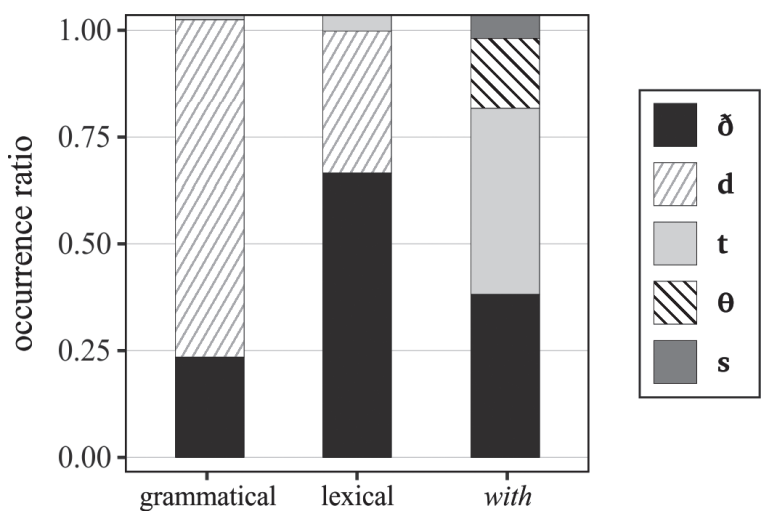

Figure 4. Proportion of realizations of the voiced dental fricative /ठ/ according to the lexical class of the word; the preposition with is shown separately (see text).

The realizations of / $/$ / are depicted for the individual speakers in Figure 5. It is interesting to compare these substitution patterns of / $/$ / with those of / $\theta /$ in Figure 3: with the exception of speaker $S 10$, those who tended to pronounce $/ \theta /$ as a dental fricative did the same with / $/$ /, and those who substituted / $\theta /$ by other consonants tended to substitute / $/$ / also most. Based on our data, we can thus draw the conclusion that the voiced dental fricative $/ ð /$ is more difficult for Czech speakers of English, especially in grammatical words.

Let us next turn to the English labiovelar approximant /w/ and the labiodental fricative $/ \mathbf{v} /$. As mentioned in section 2.2, Czech speakers may pronounce both of them incorrectly. It is obvious from Figure 6 that this is indeed the case, albeit to a much smaller extent than in the case of the dental fricatives. Both $/ \mathrm{w} /$ and $/ \mathrm{v} /$ were pronounced correctly in over $70 \%$ of all items, but individual speakers differ considerably. It seems 


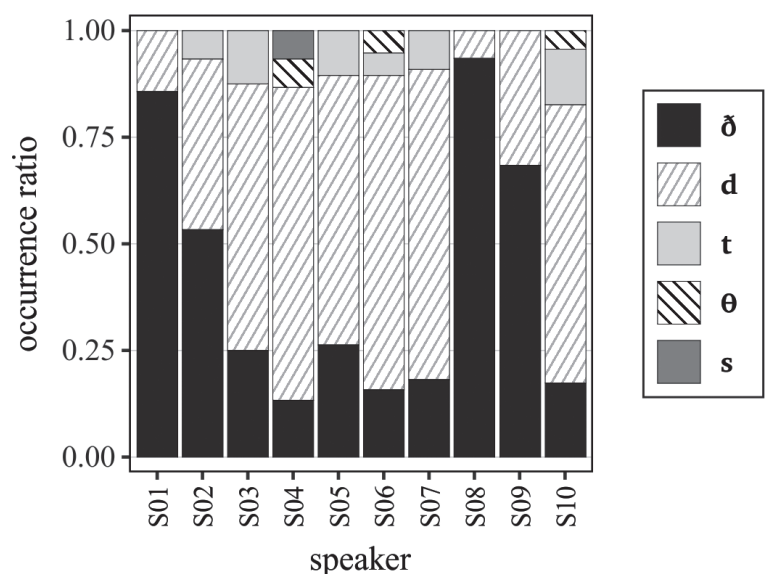

Figure 5. Proportion of realizations of the voiced dental fricative /ð/.

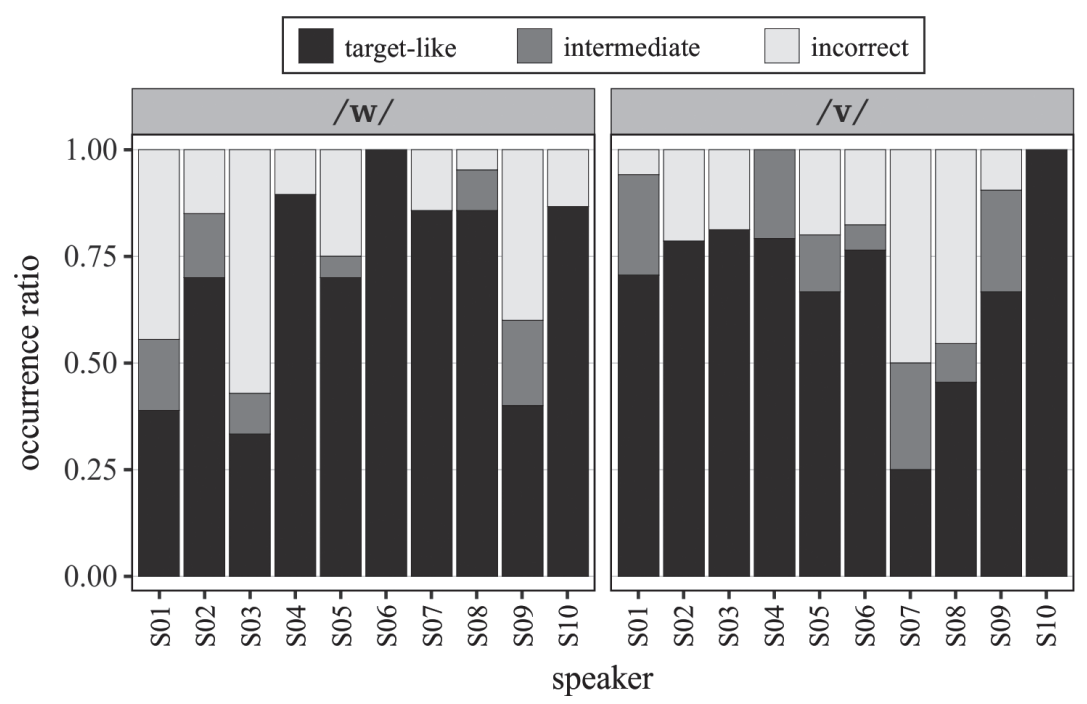

Figure 6. Proportion of target-like, intermediate, and incorrect realizations of /w/ and /v/.

that for some speakers (especially S07 and S08), there may even be partial neutralization, with sounds corresponding to both $/ \mathrm{w} /$ and $/ \mathrm{v} /$ approximating [w]. In a more detailed analysis, we examined the effect of lexical class on the pronunciation of $/ \mathrm{w} /$; unlike in the case of $/ \delta /, / w /$ was pronounced more correctly in grammatical words like was, with or will than in lexical ones like world, wide or twenty.

In the following paragraphs, we will present results concerning those consonants which function differently in English, or which are realized with noticeable phonetic differences. The velar nasal sound $/ \mathrm{y} /$, which functions as an allophonic variant of $/ \mathrm{n} /$ 


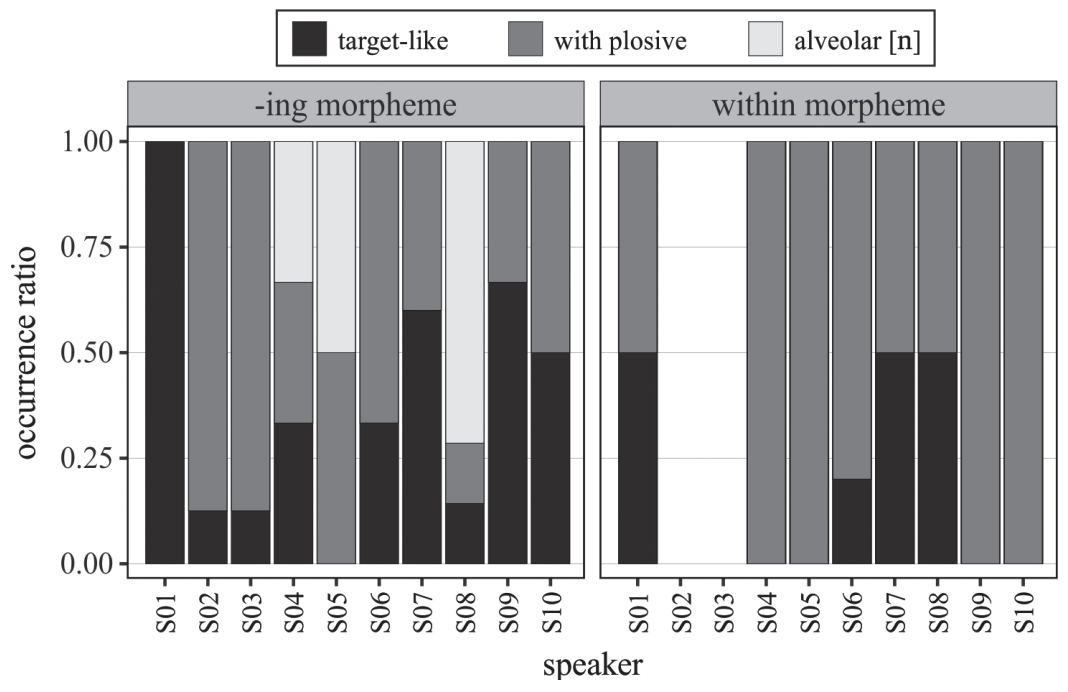

Figure 7. Proportion of realizations of $/ \mathrm{y} /$ by the ten speakers in -ing morphemes and within morphemes.

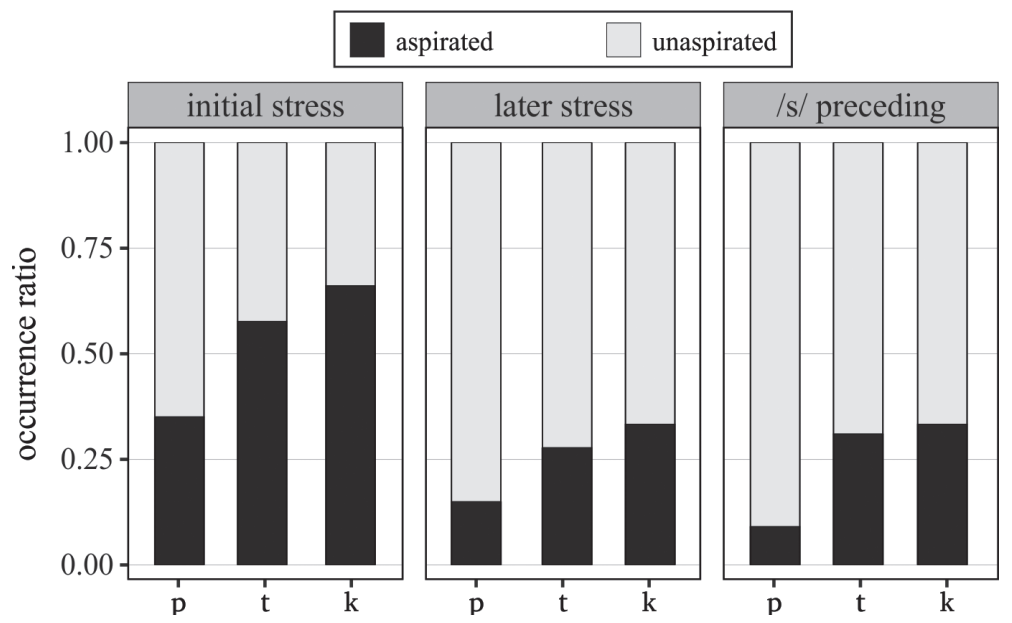

Figure 8. Proportion of aspirated and unaspirated voiceless plosives in stressed syllables at the beginning of the word, later in the word and following a $/ \mathrm{s} /$.

in Czech, was pronounced incorrectly in nearly $75 \%$ of the cases. As shown in Figure 7, the most frequent incorrect variant was one where the velar nasal [ $\mathrm{g}$ ] was followed by a plosive $[\mathrm{k}]$ or $[\mathrm{g}]$. Additionally, three speakers pronounced the alveolar [n] in words containing the progressive form; for speaker $\mathrm{S} 08$, this was in fact the most frequent realization of the -ing morphemes. Speakers S02 and S03 read the same text which featured no instance of [ $\mathrm{y}]$ within a morpheme. 
We were also interested in the realization of the /r/ sound; standard British and American English has the postalveolar or retroflex approximant [I] or [I], while Czech uses the alveolar trill [r]. The trilled pronunciation may be a stereotypical part of the sound of Czech English; however, our results show surprisingly little substitution by a trilled [r]. This was most frequen - in 7 out of 45 cases - when /r/ was preceded by a plosive sound, as in the words president, group or hundred.

The different implementation of the voicing contrast in English and Czech is most salient in aspiration. Aspiration tends to be the strongest in the onset of stressed syllables, and that is why aspiration was assessed only in stressed syllables. In Figure 8, we distinguish three contexts: the stressed syllable also being the first syllable, stress on another than the first syllable, and the voiceless plosive preceded by /s/ (there is no aspiration with /s/ preceding the plosive). Not surprisingly, $/ \mathrm{t} /$ and $/ \mathrm{k} /$ were aspirated more than /p/ (cf. Cho \& Ladefoged, 1999). More interestingly, the Czech speakers were more likely to aspirate at the beginning of the word (e.g., parliament, territory, council), in 53\% of the cases, than when a later syllable was stressed (e.g., impartial, attempt, become), in only $23 \%$ of the cases. It is also noteworthy that in $23 \%$ of the cases, the speakers aspirated even when a /s/ preceded the voiceless plosive (e.g., spokesman, street, escape), in what may be regarded as overgeneralization.

When analyzing regressive assimilation of voicing, it was necessary to exclude all cases where the Czech speakers separated the words by a pause. Approximately $40 \%$ of word-final voiceless obstruents, both fricatives and plosives, were assimilated in their voicing when a voiced sound followed (e.g., West Bank pronounced [wezd beyk]). The individual speakers differed in their tendency to assimilate voicing, with speaker S06 assimilating in over $80 \%$ of her items and speakers S01 and S03 not assimilating at all.

\subsection{Stressed and unstressed syllables}

This section will address stress placement in two-, three- and four-syllabic words where stress appears on another than the first syllable, and also the pronunciation of unstressed syllables where vowels correspond to the reduced vowel schwa in native English.

Lexical stress was misplaced to the first syllable of the word in about $50 \%$ of the cases, regardless of word length. Interestingly, as shown in Figure 9, stress was also misplaced to another (incorrect) syllable in several cases. The word effort was twice pronounced [I'fo:rt]; a similar change occurred in the word injured. As for longer words, stress was placed on the last syllable in the words communiqué and communities.

The mid central vowel /ə/ was analyzed in longer, autosemantic words like unaccept$\underline{a} b l e$, modern or opponent; that is why it is covered alongside lexical stress. As mentioned in Table 1, we were interested in the specific vocalic quality of the sounds which would be pronounced as schwa by native speakers. These realizations, as produced by the ten analyzed speakers, are summarized in Figure 10. In total, 37\% of the items were pronounced with a mid central quality of a schwa [ə] or an $r$-coloured schwa [ə] keep in mind, however, that this only refers to the quality of the vowel, not to the overall (absence of) prominence ( $c f$. Volín et al., 2013 and other studies mentioned in section 2.3). Not surprisingly, the schwa vowels were frequently realized with what is known as spelling pronunciation. The most frequent substitutes were the mid front $[e / \varepsilon]$ (in words 


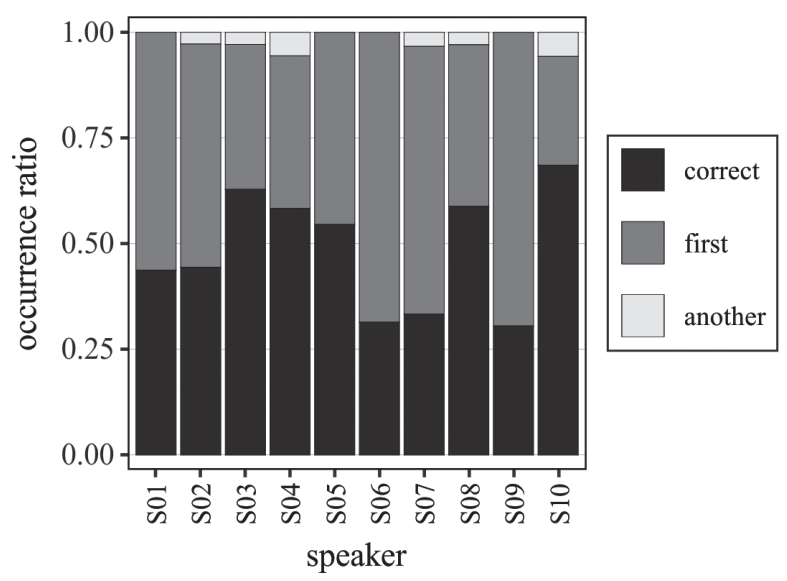

Figure 9. Proportion of words stressed correctly, incorrectly on the first syllable, and incorrectly on another syllable.

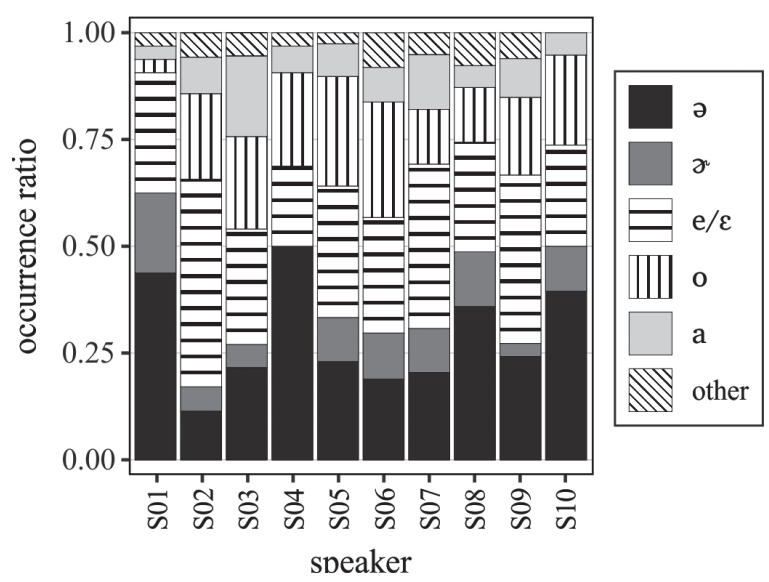

Figure 10. Realizations of vowels corresponding to schwa.

like system, operate, concentrate and also with 'a' spellings, for example company, across, England) and mid back [o] (e.g., completely, official, ceremony). An open vowel [a] was realized especially at word ends (e.g., India, idea, data) and also in words like industry or successful. The category labelled as "other" in Figure 10 includes [u] (supplies, surprise) and [I] (allegations), but also long vowels or diphthongs like [o:] (effort), [ô]] (unanimously, protester) or [ê] (affordable, cooperative). 


\subsection{Rhythmic patterning}

From the pronunciation features which contribute to the typical English rhythm, vowel reduction was addressed in the previous section. In this section, we focus on linking and glottalization. As can be seen in Figure 11, most of our speakers did not link words together much; the tendency was slightly higher when the vowel-initial word was grammatical (e.g., millions of, save it) than when it was lexical (e.g., should allow, in effect). Speaker S09 linked the most, 46\% of the cases, speaker S04 linked in 41\% of the cases, predominantly when the second word was grammatical. On the other hand, speaker S02 did not link in any of the 26 possible contexts in her text.

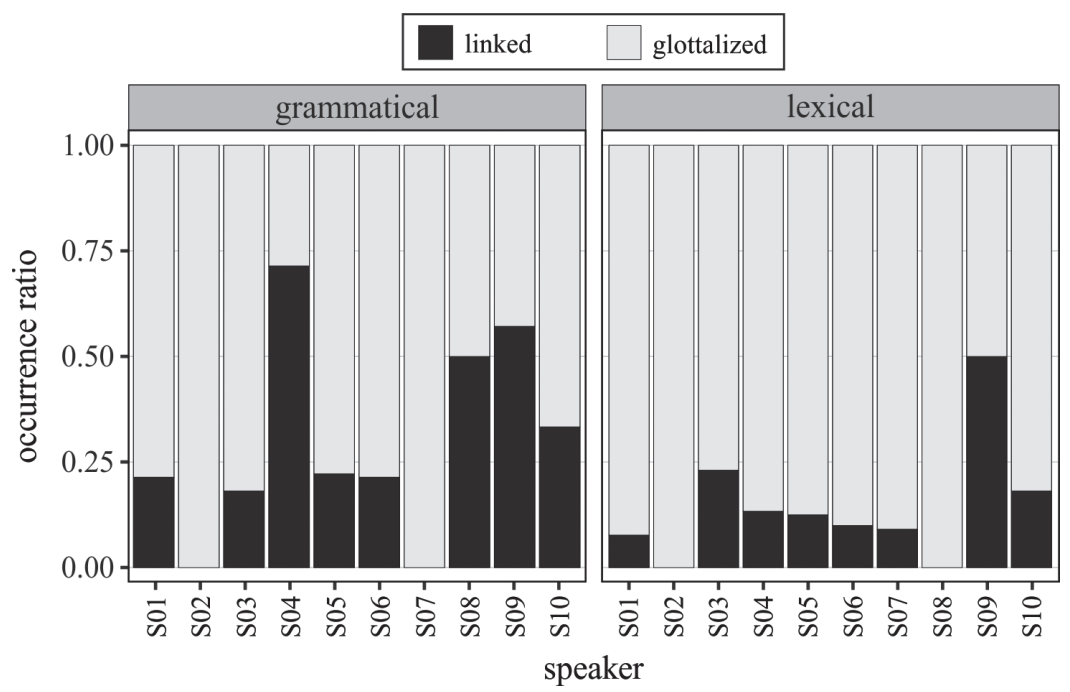

Figure 11. Proportion of linking and glottalization in grammatical and lexical words.

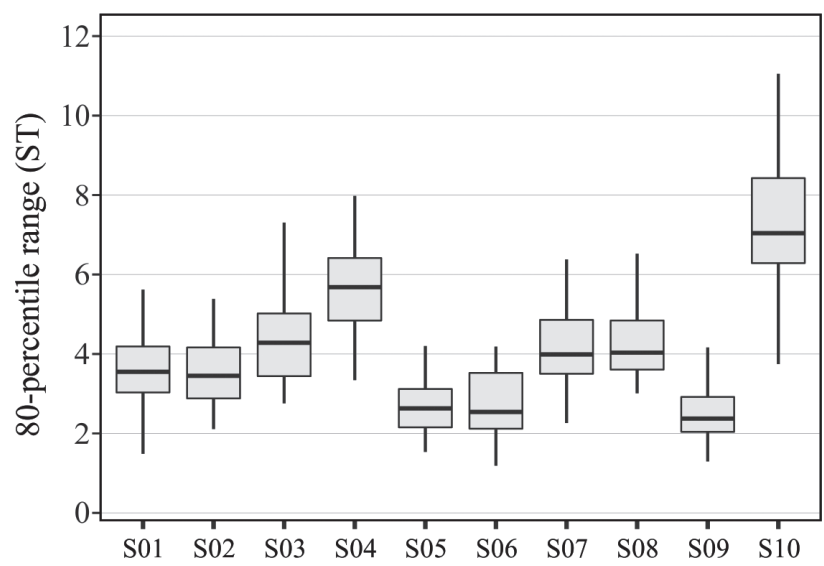

Figure 12. 80-percentile range in semitones in individual breath groups. 


\subsection{Melodic patterning}

The first feature related to intonation analyzed in this study was pitch range. As shown in Figure 12, our speakers' pitch range, as evidenced by the 80 -percentile range, was confirmed to be quite narrow; the only exception is speaker S10, whose intonation indeed strikes listeners as remarkably lively. Volín et al. (2015) reported their Czech English speakers' 80 -percentile range around 4 semitones (ST), and we can see that the median value of most of the speakers in this study moves around the same value, with three speakers' median even below 3 ST.

Finally, we were interested in the melodic step between the stressed and poststressed syllable. The difference in $f_{0}$ is illustrated in Figure 13. If we regard the $<-0.5$; $0.5>$ ST range as level, since just noticeable difference corresponds to approximately one half of a semitone (Klatt, 1973), it is clear that there are considerably more post-stress rises than there are falls. Only in speaker S09 can we see more falls than rises, but this speaker also displays a lot of "level" steps. To summarize, most of the Czech speakers analyzed in this study tended to pronounce the second syllable in a stress group as higher than the stressed one.

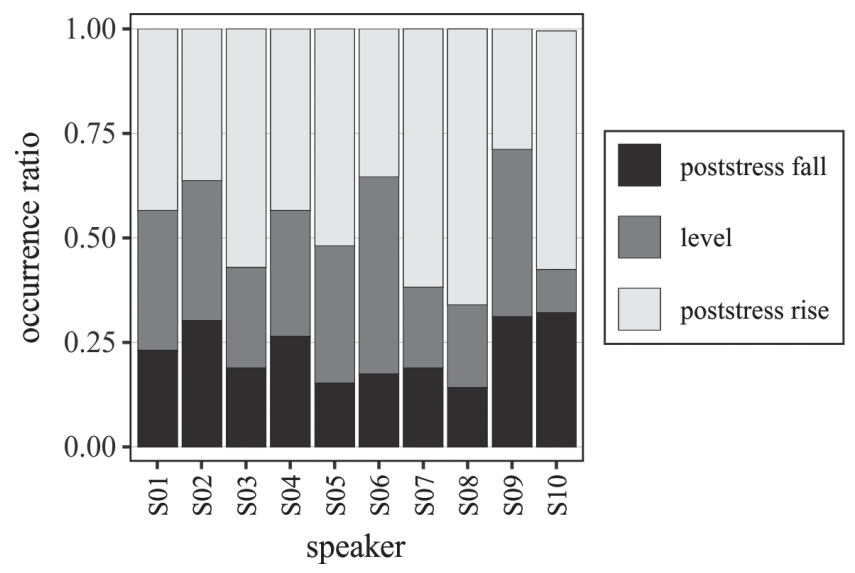

Figure 13. Occurrence of $f_{0}$ relationships between the stressed and post-stressed vowel.

\section{General discussion and conclusion}

The objective of this study was to investigate several pronunciation features which have either been shown by previous research or known based on observation to cause problems to Czech speakers of English. In what, to our best knowledge, is to date the most comprehensive analysis of Czech English pronunciation, we examined ten female speakers with a strong accent in their English, focusing on both segmental and prosodic features. The scope of the analyses, while being a decisive advantage, also constitutes one of the limitations of the current study: the pronunciation features were assessed using different approaches (auditory and acoustic), and the auditory analyses made use of dif- 
ferent evaluation scales, as suitable for the particular pronunciation features. However, we are convinced that these drawbacks are outweighed by the benefit of the uniform and consistent approach to the auditory analyses.

The results of this study are summarized in Table 2; the table may serve as a schematic illustration, allowing one to compare the individual pronunciation features and speakers. In accordance with the previous displays, the darkest shade of grey corresponds to most target-like pronunciation. It should be noted that some of the analyses presented above did not include by-speaker display, so that the table contains details beyond those described in section 4 .

Table 2. Schematic representation of the speakers' realization of the analyzed features. Dark represents mostly target-like pronunciation, light represents mostly "Czech-like" pronunciation, grey an intermediate step corresponding to inconsistent performance.

\begin{tabular}{|c|c|c|c|c|c|c|c|c|c|c|c|c|}
\hline & $\begin{array}{l}0 \\
\& \\
0 \\
0 \\
0 \\
0 \\
0\end{array}$ & $\begin{array}{l}\text { to } \\
0\end{array}$ & $\begin{array}{l}7 \\
3\end{array}$ & 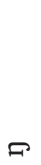 & 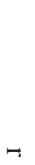 & 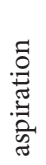 & 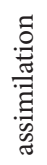 & 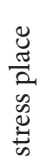 & 党 & 堷 & 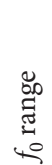 & $\begin{array}{l}\stackrel{0}{0} \\
0 \\
\stackrel{0}{0} \\
0 \\
\dot{1} \\
\dot{0} \\
0\end{array}$ \\
\hline S01 & & & & & & & & & & & & \\
\hline S02 & & & & & & & & & & & & \\
\hline S03 & & & & & & & & & & & & \\
\hline S04 & & & & & & & & & & & & \\
\hline S05 & & & & & & & & & & & & \\
\hline S06 & & & & & & & & & & & & \\
\hline S07 & & & & & & & & & & & & \\
\hline S08 & & & & & & & & & & & & \\
\hline S09 & & & & & & & & & & & & \\
\hline S10 & & & & & & & & & & & & \\
\hline
\end{tabular}

It is immediately apparent, for instance, that none of the speakers analyzed here pronounced the English / $\mathrm{r}$ / consistently as an alveolar trill: in what we consider a surprising result, seven of the speakers mostly pronounced $/ r /$ as an approximant. Similarly, the difference between /v/ and /w/ was not a problem for half of the speakers, with the other half being less consistent in their pronunciation. From the other end of the scale, we can see that the pronunciation of the two open vowels, /æ/ and /p/, is inconsistent at best (in speakers S06 and S07) and Czech-like for most of the speakers. Similarly, most of the speakers failed to link most of the times, pronounce $/ \mathrm{y} /$ without a following plosive, and their intonation range was very compressed in comparison with native speakers of English.

Turning to individual speakers, the table elegantly shows that although all of them have been evaluated as having a relatively strong Czech accent in their English, they differ in their pronunciation of the individual features. Speaker S07 is the only one who did not manifest target-like pronunciation of at least one of the features. All of the others 
show a satisfactory performance in at least two pronunciation features, most frequently the above-mentioned / $/ \mathrm{r}$ and / $\mathrm{w}-\mathrm{v} /$. To summarize, it is clear that the label strong Czech accent may be "filled" in different ways, that it may refer to diverse constellations of pronunciation features. Of course, this is not surprising, as speech is a multidimensional phenomenon; in this study, we tried to provide a glimpse of those dimensions most associated with Czech English.

\section{ACKNOWLEDGEMENTS}

This study was supported by the European Regional Development Fund-Project "Creativity and Adaptability as Conditions of the Success of Europe in an Interrelated World" (No. CZ.02.1.01/0.0/0.0/16_019/0000734).

\section{REFERENCES}

Abercrombie, D. (1949). Teaching Pronunciation. ELT Journal, 3(5), 113-122.

Alameen, G. \& Levis, J. M. (2015). Connected speech. In: Reed, M. \& Levis, J. M. (Eds.), The Handbook of English Pronunciation, 159-174. Oxford: Wiley Blackwell.

Bissiri, M. \& Volín, J. (2010). Prosodic structure as a predictor of glottal stops before word-initial vowels in Czech English. In: Vích, R. (Ed.), Speech Processing, 23-28. Praha: Institute of Photonics and Electronics, CAS.

Boersma, P. \& Weenink, D. (2018). Praat: doing phonetics by computer, version 6.0.41. Retrieved August 6, 2018 from http://www.praat.org/.

Bořil, T. \& Skarnitzl, R. (2016). Tools rPraat and mPraat: Interfacing phonetic analyses with signal processing. In: Sojka, P., Horák, A., Kopeček, I. \& Pala, K. (Eds.), Proceedings of the 19th International Conference on Text, Speech and Dialogue, 367-374. Cham: Springer International Publishing.

Brown, A. (2016). Barriers to learning the English th sounds II: The relative importance of the two sounds. Speak Out! (Journal of the IATEFL Pronunciation Special Interest Group), 54, 6-14.

Červinková Poesová, K. \& Weingartová, L. (2018). Character of vowel reduction in Czech English. In: Volín, J. \& Skarnitzl, R. (Eds.), The Pronunciation of English by Speakers of Other Languages, 96-116. Newcastle upon Tyne: Cambridge Scholars Publishing.

Cho, T. \& Ladefoged, P. (1999). Variation and universals in VOT: evidence from 18 languages. Journal of Phonetics, 27, 207-229.

Crystal, D. (2002). The English Language: A Guided Tour of the Language. 2nd ed. London: Penguin Books.

Derwing, T. M. \& Munro, M. J. (2009). Putting accent in its place: Rethinking obstacles to communication. Language Teaching, 42(4), 476-490.

Derwing, T. M. \& Munro, M. J. (2015). Pronunciation Fundamentals: Evidence-based Perspectives for L2 Teaching and Research. Amsterdam: John Benjamins Publishing Company.

Eriksson, A. \& Heldner, M. (2015). The acoustics of word stress in English as a function of stress level and speaking style. In: Proceedings of Interspeech 2015, 41-45.

Flege, J. E. (1987). The production of "new" and "similar" phones in a foreign language: evidence for the effect of equivalence classification. Journal of Phonetics, 15, 47-65.

Hawkins, S. \& Midgley, J. (2005). Formant frequencies of RP monophthongs in four age groups of speakers. Journal of the International Phonetic Association, 35(2), 183-199.

Klatt, D. H. (1973). Discrimination of fundamental frequency contours in synthetic speech: Implications for models of speech perception. Journal of the Acoustical Society of America, 53, 8-16. 
Levis, J. M. (2005). Changing contexts and shifting paradigms in pronunciation teaching. TESOL Quarterly, 39(3), 369-377.

Levis, J. M. (2018). Intelligibility, Oral Communication, and the Teaching of Pronunciation. Cambridge: Cambridge University Press.

Munro, M. J. \& Derwing, T. M. (1995). Foreign accent, comprehensibility, and intelligibility in the speech of second language learners. Language Learning, 45(1), 73-97.

Munro, M. J. \& Derwing, T. M. (2006). The functional load principle in ESL pronunciation instruction: An exploratory study. System, 34(4), 520-531.

Palková, Z. \& Volín, J. (2003). The role of F0 contours in determining foot boundaries in Czech. In: Proceedings of 15th International Congress of Phonetic Sciences, 1783-1786.

Pospísilová, A. (2011). Aspiration of English plosives in Czech students of English studies. Praha: Faculty of Arts, Charles University. (unpublished bachelor thesis)

R Core Team (2017). R: A language and environment for statistical computing (version 3.3.2). Vienna: R Foundation for Statistical Computing. Retrieved from http://www.Rproject.org.

Skarnitzl, R. (2001). Teaching and Learning the English Dental Fricatives in the Czech Environment. Praha: Faculty of Education, Charles University. (unpublished diploma thesis)

Skarnitzl, R. (2004). Fonotaktické chování velární nazály v české angličtině. In: Duběda, T. (Ed.), Konference česko-slovenské pobočky ISPhS 2004, 75-83.

Skarnitzl, R. (2018). Fonetická realizace slovního přízvuku u delších slov v češtině. Slovo a slovesnost, 79, 199-216.

Skarnitzl, R. \& Šturm, P. (2016). Pre-fortis shortening in Czech English: A production and reaction-time study. Research in Language, 14, 1-14.

Skarnitzl, R. \& Šturm, P. (2017). Voicing assimilation in Czech and Slovak speakers of English: Interactions of segmental context, language and strength of foreign accent. Language and Speech, 60, 427-453.

Skarnitzl, R. \& Volín, J. (2012). Referenční hodnoty vokalických formantů pro mladé dospělé mluvčí standardní češtiny. Akustické listy, 18, 7-11.

Skarnitzl, R., Volín, J. \& Drenková, L. (2005). Tangibility of foreign accents in speech: The case of Czech English. In: Grmelová, A., Dušková, L. \& Farrell, M. (Eds.), 2nd Prague Conference on Linguistics and Literary Studies Proceedings, 11-20. Praha: PedF UK.

Šimáčková, Š. (2003). "Engela’s Eshes": Cross-linguistic perception and production of English $[æ]$ and $[\varepsilon]$ by Czech EFL learners trained in phonetics. In: Proc. of 15th ICPhS, 2293-2296.

Šimáčková, Š., Kolářová, K. \& Podlipský, V. J. (2014). Tempo and connectedness of Czech-accented English speech. Concordia Working Papers in Applied Linguistics, 5, 667-677.

Šimáčková, Š. \& Podlipský, V. J. (2018). Production accuracy of L2 vowels: Phonological parsimony and phonetic flexibility. Research in Language, 16(2), 169-191.

Šimáčková, Š., Podlipský, V. J. \& Koláŕová, K. (2014). Linking versus glottalization: (Dis)connectedness of Czech-accented English. Concordia Working Papers in Applied Linguistics, 5, 678-692.

Šturm, P. \& Skarnitzl, R. (2011). The open front vowel /æ/ in the production and perception of Czech students of English. In: Proceedings of Interspeech 2011, 1161-1164.

Volín, J. (2008). Z intonace čtených zpravodajství: výška první slabiky v taktu. Čeština doma a ve světě, 2008 (1-2), 89-96.

Volín, J. \& Johaníková, T. (2018). Weak structural words in British and Czech English. In: Volín, J. \& Skarnitzl, R. (Eds.), The Pronunciation of English by Speakers of Other Languages, 181-195. Newcastle upon Tyne: Cambridge Scholars Publishing.

Volín, J., Poesová, K. \& Weingartová, L. (2015). Speech melody properties in English, Czech and Czech English: Reference and interference. Research in Language, 13, 107-123.

Volín, J., Weingartová, L. \& Skarnitzl, R. (2013). Spectral characteristics of schwa in Czech accented English. Research in Language, 11, 31-39.

Weingartová, L., Poesová, K. \& Volín, J. (2014). Prominence contrasts in Czech English as a predictor of learner's proficiency. In: Proceedings of Speech Prosody 2014, 236-240.

Wichmann, A. (2005). The role of intonation in the expression of attitudinal meaning. English Language and Linguistics, 9(2), 229-253.

Wickham, H. (2009). ggplot2: Elegant graphics for data analysis. New York: Springer. 


\section{RESUMÉ}

Př́íspěvek se věnuje zvukové podobě angličtiny českých mluvčích, kteří ve své angličtině vykazují silný cizinecký přízvuk. Jako první studie se systematicky věnuje většímu množství výslovnostních segmentálních i prozodických rysů, které jsou s českou angličtinou spojovány nebo které již u českých mluvčích angličtiny byly zkoumány. Studie je založena na kombinace poslechových a akustických analýz deseti mluvčích se silným př́ízvukem. Výsledky ukazují, že v segmentální oblasti mluvčí téměř výhradně vyslovují namísto anglických otevřených samohlásek /æ $\mathrm{p} /$ jejich české středové ekvivalenty. Velární nazála bývá ve slovech chybně následována velární explozivou. V řeči analyzovaných mluvčích se jen zřídka vyskytovalo vázání slov a jejich intonační rozpětí je většinou velmi ploché. U některých dalších výslovnostních jevů, např́ílad u aspirace, realizace dentálních frikativ nebo v umístění lexikálního př́ízvuku, se však mluvčí liší. Výsledky tak zdůrazňují skutečnost, že „silný český př́ízvuk v angličtině“ je označení, které může odpovídat různým konstelacím výslovnostních jevů.

\section{Radek Skarnitzl}

Institute of Phonetics

Faculty of Arts, Charles University

Prague, Czech Republic

E-mail: radek.skarnitzl@ff.cuni.cz

\section{Jana Rumlová}

Department of English Language and ELT Methodology

Faculty of Arts, Charles University

Prague, Czech Republic 